\title{
In vitro evaluation of the effects of frequently prescribed pediatric drugs on the microhardness of permanent tooth enamel
}

\section{Ocena in vitro oddziaływań często stosowanych leków pediatrycznych na mikrotwardość szkliwa zębów stałych}

\author{
Nagehan Yılmaz ${ }^{1, D}$, Ozgul Baygin ${ }^{1, A}$, Tugba Nigar Cakıroglư ${ }^{2, B}$, Tamer Tüzüner ${ }^{1, C}$, Orhan Deger, ${ }^{3, E}$ \\ 1 Department of Pediatric Dentistry, Faculty of Dentistry, Karadeniz Technical University, Trabzon, Turkey \\ ${ }^{2}$ Department of Biochemistry, Faculty of Medicine, Avrasya University, Trabzon, Turkey \\ ${ }^{3}$ Department of Biochemistry, Faculty of Medicine, Karadeniz Technical University, Trabzon, Turkey \\ A - research concept and design; $\mathrm{B}$ - collection and/or assembly of data; $\mathrm{C}$ - data analysis and interpretation; \\ $D$ - writing the article; $E$ - critical revision of the article; $F$ - final approval of the article
}

Address for correspondence

Ozgul Baygin

E-mail:dtozgul@gmail.com

\section{Funding sources}

None declared

\section{Conflict of interest \\ None declared}

\section{Acknowledgements}

The authors thank the Ph. D. student Cevriye Ceyda Kolaylı for the statistical analysis and the Ph. D. student Serdar Özkaya for help with the measurements of the microhardness of the samples.

Received on January 3, 2019

Reviewed on February 14, 2019

Accepted on March 12, 2019

Published online on June 28, 2019

\section{Cite as}

Y.Imaz N, Baygin 0, Cakiroglu TN, Tüzüner T, Deger 0. In vitro evaluation of the effects of frequently prescribed pediatric drugs on the microhardness of permanent tooth enamel. DentMed Probl. 2019;56(2):131-136. doi:10.17219/dmp/105562

D0I

$10.17219 / \mathrm{dmp} / 105562$

Copyright

○ 2019 by Wroclaw Medical University

This is an article distributed under the terms of the

Creative Commons Attribution 3.0 Unported License (CC BY 3.0)

(https://creativecommons.org/licenses/by/3.0/)

\section{Abstract}

Background. Dental erosion is considered one of the oral cavity diseases. Frequent intake of liquid oral medications can be an effective factor in tooth erosion.

Objectives. This study aimed to evaluate the effects of frequently prescribed pediatric drugs on the permanent dental enamel microhardness over a period of 14 days in vitro.

Material and methods. In this study, 11 pediatric drugs with different active ingredients were used; the control group consisted of teeth immersed in distilled water. The immersion cycles were applied 3 times a day for $1 \mathrm{~min}$. The measurements of the samples prepared were taken at 0 (baseline), 7 and 14 days after the immersion cycles using a Vickers hardness testing machine. The pH, itrratable acidity (TA) and buffering capacity of the syrups were assessed.

Results. The measurements of the tooth samples that were immersed in drug solutions except Deltacortri ${ }^{\circledR}$ showed that there was a significant difference between days 0,7 and 14 . The microhardness values for the tooth samples that were immersed in the Deltacortril drug solution decreased, but no significant difference was found. There were no statistically significant differences between the day 0,7 and 14 measurements in the control group.

Conclusions. Commonly used and prescribed pediatric drugs pose a risk for tooth erosion. Pediatricians should be aware of the effects of prescription drugs on erosion, and stress the need for compliancy with oral hygiene procedures.

Key words: microhardness, dental erosion, pediatric syrup, permanent dental enamel

Słowa kluczowe: mikrotwardość, erozja zębów, syrop dla dzieci, szkliwo zębów stałych 


\section{Introduction}

Oral health is known to have a direct impact on the growth, development and general health of children. Dental erosion is considered one of the oral cavity diseases $^{1,2}$ and is defined as irreversible progressive loss of hard dental tissues by chemical dissolution without bacterial involvement. ${ }^{3}$ It has been reported that when the $\mathrm{pH}$ of the oral environment reaches a critical cutoff value of 5.5, the demineralization of the enamel will occur. ${ }^{4}$ The erosion begins with the softening of the enamel surface, mainly characterized by a reduction in microhardness. ${ }^{5}$ This erosion is a multifactorial, irreversible process resulting from internal, external or idiopathic factors. ${ }^{6}$ Intrinsic etiological factors, which are caused by the contact of dental tissue with stomach acids, include eating disorders, regurgitation and reflux $^{7}$; acidic drugs, diet, environment, and behavioral factors are external etiological factors. ${ }^{8-12}$

Changing habits in modern society, especially in children and adolescents, have increased the incidence of tooth erosion ${ }^{6,12,13}$ and have been associated with the regular use of products with high acidity, low concentration of calcium, fluoride and phosphate ions, and low endogenous $\mathrm{pH} .^{8,14}$ Although erosion can be seen frequently in children, it can be observed in conjunction with other forms: attrition (tooth-tooth wear), abrasion (hard surface-tooth) and abfraction. Epidemiological data collected during in vitro and in situ studies has shown that erosion, one of the 3 toothwear processes, is the most common cause of tooth surface loss. ${ }^{15,16}$ Erosion was first included in the dental health surveys of children living in England in 1993 and since that time has been periodically surveyed. The prevalence of erosion has been shown to have increased in the studies between 1993 and 1997 among children aged $4-18$ years. ${ }^{17}$

The general health of the child plays an important role in the development of tooth erosion. Liquid pediatric medicines are part of the daily routine of children with chronic illnesses. Frequent intake of drugs with erosive potential can be an effective factor in tooth erosion. ${ }^{12,18}$ Liquid oral medications are usually prescribed to ensure compliancy with drug intake in children. ${ }^{10}$ Acidic preparations are considered necessary for drug distribution, chemical stability, physiological adaptation, and flavor enhancement. ${ }^{9,10}$ In addition to the acidic components, consumption frequency and duration, use between sleeping or consuming food, high viscosity, and factors that reduce the salivary flow promote tooth erosion. ${ }^{12,13,19}$

Therefore, due to the increased use of oral medications in recent years in children with acute or chronic diseases, this study aimed to evaluate the effects of frequently prescribed pediatric drugs on the permanent dental enamel microhardness in vitro.

\section{Material and methods}

For the study, ethics committee approval was obtained from the Scientific Research Ethics Committee of the Faculty of Medicine at Karadeniz Technical University, Trabzon, Turkey (approval No. 2016/68).

\section{Experimental design}

In the study, 11 pediatric drugs with different active ingredients were used; the control group consisted of teeth immersed in distilled water. The drugs used were selected among long-term and commonly used medicines that are frequently prescribed by pediatricians for acute or chronic diseases (Table 1). The immersion cycles were applied 3 times a day for $1 \mathrm{~min}$. The measurements of the samples prepared were repeated at 0 (baseline), 7 and 14 days after the immersion cycles. Microhardness was measured using a Vickers hardness tester (INNOVATEST Europe BV, Maastricht, the Netherlands).

\section{Tooth selection}

In this study, 48 non-cariogenic, healthy, permanent molar teeth that were freshly extracted were used. Once the teeth were collected, they were kept in a $0.5 \%$ chloramine $\mathrm{T}$ solution. Prior to use, the teeth were cleaned with a pumice/water slurry using a polishing brush with a low-speed handpiece. Teeth with molar incisor hypoplasia, or decayed and with white spot lesions were not included in the study.

\section{Preparation of samples}

While the samples were being prepared, the teeth were separated from their roots by a transverse section through the cementoenamel junction with the help of a watercooled diamond saw with a rapidly rotating handpiece. Subsequently, each crown was split into 2 pieces with axial cuts to obtain buccal and lingual surface measurements. Each crown was fixed with plastic wax on an acrylic plate.

Seven tooth crowns with buccal surfaces faced upward using a parallelometer (ElQuip, São Carlos, São Paulo, Brazil) to secure the flattest region of the buccal surface parallel to the plate, were fixed in each acrylic block (1 extra to substitute).

After the resin acrylic polymerization of each surface, the buccal enamel surfaces of the samples were flattened with 600, 900 and 1200 grit aluminum oxide $\left(\mathrm{Al}_{2} \mathrm{O}_{3}\right)$ abrasive papers for non-slip measurements and to obtain a flat, stable surface without the dentin coming out. The samples were ultrasonically cleaned in deionized water for $10 \mathrm{~min}$ and sterilized in deionized water. The $0.5 \times 0.5 \mathrm{~mm}$ quadratic specimens were centered at a diameter of $0.5 \mathrm{~mm}$ from the center (the tooth/plate sets were rendered acid-proof by coating them with 2 layers of cosmetic nail polish isolation). Prior to the immersion 
Table 1. Characteristics of the studied drugs

\begin{tabular}{|c|c|c|c|c|c|}
\hline Therapeutic class & General name & Brand name & Pharmaceutical form & $\mathrm{mg} / \mathrm{mL}$ & Manufacturer \\
\hline Antibiotics & $\begin{array}{c}\text { amoxicillin + clavulanic acid } \\
\text { clarithromycin } \\
\text { cefuroxime axetil }\end{array}$ & $\begin{array}{l}\text { Augmentin }{ }^{\circledR} \\
\text { Macrol }^{\circledR} \\
\text { Cefaks }^{\circledR}\end{array}$ & $\begin{array}{l}\text { dry powder to prepare } \\
\text { oral suspension }\end{array}$ & $\begin{array}{l}600 / 42.9 / 5 \\
250 / 5 \\
250 / 5\end{array}$ & $\begin{array}{c}\text { GlaxoSmithKline, London, UK } \\
\text { Sanovel, Istanbul, Turkey } \\
\text { Deva, Istanbul, Turkey }\end{array}$ \\
\hline Antiepileptics & levetiracetam & Keppra ${ }^{\circledR}$ & syrup & 100 & GlaxoSmithKline \\
\hline Multivitamins & multivitamins & Ferro Sanol ${ }^{\circledR} \mathrm{B}$ & syrup & $150 / 5$ & ADEKA, Tokyo, Japan \\
\hline Analgesics & $\begin{array}{l}\text { paracetamol } \\
\text { ibuprofen }\end{array}$ & $\begin{array}{c}\text { Calpol }^{\circledR} 6 \text { Plus } \\
\text { Dolven }\end{array}$ & syrup & $\begin{array}{l}250 / 5 \\
100 / 5\end{array}$ & $\begin{array}{l}\text { GlaxoSmithKline } \\
\text { Sanofi, Paris, France }\end{array}$ \\
\hline Anxiolytic & hydroxyzine $\mathrm{HCl}$ & Atarax $^{\circledR}$ & syrup & 2 & UCB, Brussels, Belgium \\
\hline Bronchodilator & salbutamol & Ventolin ${ }^{\circledR}$ & syrup & $2 / 5$ & GlaxoSmithKline \\
\hline Sympathomimetic & pseudoephedrine $\mathrm{HCl}$ & Sudafed ${ }^{\circledR}$ & syrup & $30 / 5$ & GlaxoSmithKline \\
\hline Corticosteroids & prednisolone & Deltacortril ${ }^{\circledR}$ & tablet & 5 & Pfizer, New York, USA \\
\hline
\end{tabular}

cycles, the samples were kept in distilled water for $24 \mathrm{~h}$ at $37^{\circ} \mathrm{C}$. The microhardness values of the initial enamel surfaces were evaluated using a Vickers hardness tester (INNOVATEST Europe BV). The settings for load and penetration were determined as $50 \mathrm{~g}$ and $10 \mathrm{~s}$, respectively. The measurements were carried out at 2 separate points, each measurement at an interval of $100 \mu \mathrm{m}$ from the center of the enamel surface, with a diamond indenter, and the average of the measurements was recorded as the Vickers hardness number. ${ }^{2,12}$

\section{Composition of artificial saliva}

Artificial saliva was prepared from sodium chloride $(0.4 \mathrm{~g} / \mathrm{L})$, potassium chloride $(0.4 \mathrm{~g} / \mathrm{L})$, calcium chloride- $\mathrm{H}_{2} \mathrm{O}(0.795 \mathrm{~g} / \mathrm{L})$, sodium dihydrogen phosphate- $\mathrm{H}_{2} \mathrm{O}$ $(0.69 \mathrm{~g} / \mathrm{L})$, and sodium sulfide- $9 \mathrm{H}_{2} \mathrm{O}(0.005 \mathrm{~g} / \mathrm{L})$ in $1000 \mathrm{~mL}$ of distilled water. ${ }^{20}$

\section{pH measurement and buffering capacity}

The $\mathrm{pH}$ value of the syrups used for the immersion cycles and the amount of base (acid-base titration) required to raise $\mathrm{pH}$ to 7.0 were measured with a $\mathrm{pH}$ meter (HI 2211 pH/ORP Meter; Hanna Instruments, Woonsocket, USA). To measure the titratable acidity (TA), $20 \mathrm{~g}$ of each solution was titrated with $0.5 \mathrm{M} \mathrm{NaOH}$ in 0.02 -milliliter increments at $25^{\circ} \mathrm{C}$. The buffering capacity $(\mathrm{BC})$ was calculated with the following equation:

$$
\beta=-\Delta \mathrm{C} / \Delta \mathrm{pH}
$$

where:

$\beta$ - buffering capacity;

$\Delta \mathrm{C}$ - the amount of base used;

$\Delta \mathrm{pH}$ - the change in $\mathrm{pH}$ resulting from base addition. ${ }^{12}$

\section{Immersion cycles}

After the first microhardness measurements, 12 acrylic blocks were assigned randomly to 11 separate drugs for the samples to be immersed in the drugs; 1 of them was assigned to distilled water (the control group). During the immersion cycles, the samples were submerged for 1 min every $8 \mathrm{~h}, 3$ times a day, in $10 \mathrm{~mL}$ of an undiluted drug solution. During each immersion cycle, the solutions were mixed prior to the immersion to ensure the homogeneity of the drug solutions. After each immersion cycle, the samples were washed with distilled water, and until the next immersion cycle, they were kept in $10 \mathrm{~mL}$ of artificial saliva at a temperature of $37^{\circ} \mathrm{C}$ using the method determined by McKnightHanes and Whitford ${ }^{21}$ and modified by Amaechi et al..$^{22}$

This procedure was repeated for 2 weeks and a total of 42 immersion cycles were performed. The solutions and artificial saliva were changed daily for each sample. In the control group, the distilled water was changed daily.

The surface microhardness was tested at 7 and 14 days after continuous and systematic repetition of the daily immersion cycles. The samples were kept in distilled water during the days they were tested.

\section{Statistical analysis}

The IBM SPSS Statistics for Windows v. 23 (IBM Corp., Armonk, USA) was used in the analysis of the data. For the comparison of the data measured for 3 or more dependent groups, the analysis of variance was used. The paired comparisons of the results were evaluated using the Bonferroni test for significance. The significance level was set as $p<0.05$.

\section{Results}

\section{$\mathrm{pH}$, titratable acidity and buffering capacity}

The $\mathrm{pH}$ values ranged from 2.76 (pseudoephedrine $\mathrm{HCl}$ ) to 6.62 (paracetamol) (Table 2). Ibuprofen had the highest TA (3750 mmol), whereas prednisolone had the lowest TA ( $40 \mathrm{mmol}$ ). Additionally, pseudoephedrine $\mathrm{HCl}$ had the highest $\mathrm{BC}(3246 \mathrm{mmol})$ and prednisolone had the lowest BC (71 mmol) (Table 2). 
Table 2. The $\mathrm{pH}$, titratable acidity (TA) and buffering capacity $(\mathrm{BC})$ values of the drug solutions with the volume of $\mathrm{NaOH}\left(\mathrm{V}_{\mathrm{NaOH}}\right)$

\begin{tabular}{|l|r|rrrr}
$\begin{array}{l}\text { Pharmaceutical } \\
\text { name }\end{array}$ & pH & \multicolumn{1}{c}{$\mathrm{V}_{\mathrm{NaOH}}$} & \multicolumn{1}{c}{$\begin{array}{c}\text { Titratable } \\
\text { acidity }\end{array}$} & \multicolumn{1}{c}{$\begin{array}{c}\text { Buffering } \\
\text { capacity }\end{array}$} \\
\hline Keppra & 5.83 & $0.8 \mathrm{~mL}$ & $400 \mathrm{mmol}$ & $342 \mathrm{mmol}$ \\
Cefaks & 5.86 & $1.6 \mathrm{~mL}$ & $800 \mathrm{mmol}$ & $702 \mathrm{mmol}$ \\
Macrol & 5.15 & $1.5 \mathrm{~mL}$ & $750 \mathrm{mmol}$ & $405 \mathrm{mmol}$ \\
Ferro Sanol B & 2.86 & $7 \mathrm{~mL}$ & $3500 \mathrm{mmol}$ & $845 \mathrm{mmol}$ \\
Calpol 6 Plus & 6.62 & $0.4 \mathrm{~mL}$ & $200 \mathrm{mmol}$ & $526 \mathrm{mmol}$ \\
Atarax & 2.84 & $2 \mathrm{~mL}$ & $1000 \mathrm{mmol}$ & $240 \mathrm{mmol}$ \\
Ventolin & 3.58 & $6 \mathrm{~mL}$ & $3000 \mathrm{mmol}$ & $877 \mathrm{mmol}$ \\
Augmentin & 5.70 & $0.8 \mathrm{~mL}$ & $400 \mathrm{mmol}$ & $308 \mathrm{mmol}$ \\
Dolven & 4.38 & $7.5 \mathrm{~mL}$ & $3750 \mathrm{mmol}$ & $1431 \mathrm{mmol}$ \\
Sudafed & 2.76 & $6.5 \mathrm{~mL}$ & $3250 \mathrm{mmol}$ & $3246 \mathrm{mmol}$ \\
Deltacortril & 6.36 & $0.02 \mathrm{~mL}$ & $40 \mathrm{mmol}$ & $71 \mathrm{mmol}$ \\
Distilled water & 6.90 & - & - & - \\
\hline
\end{tabular}

\section{Surface microhardness}

The measurements of the tooth samples, which were immersed in the Keppra, Cefaks, Macrol, Ferro Sanol B, Calpol 6 Plus, Atarax, Ventolin, Augmentin, Dolven, and Sudafed drug solutions demonstrated a significant difference between days 0,7 and 14 of the study $(p<0.001, p=0.037$, $p=0.017, p=0.002, p=0.037, p<0.001, p<0.001, p=0.017$, $p<0.001$, and $p<0.001$, respectively). The microhardness values of the tooth samples that were immersed in the Deltacortril drug solution on days 0,7 , and 14 were decreased, but no significant difference was found $(p=0.191)$. There was no statistically significant difference between the day 0,7 , and 14 measurements in the control group $(p=0.54)$ (Table 3).

Table 3. Measurement of the microhardness of the tooth samples immersed in the drug solutions on days 0,7 and 14

\begin{tabular}{|l|c|c|c|c|}
\hline $\begin{array}{l}\text { Pharmaceutical } \\
\text { name }\end{array}$ & $\begin{array}{c}\text { Day 0 } \\
\text { (baseline) }\end{array}$ & \multicolumn{1}{c}{ Day 7 } & Day 14 & $p$-value \\
\hline Keppra & $276.7 \pm 28.8^{\mathrm{a}}$ & $181.1 \pm 32.4$ & $197.6 \pm 17.0$ & $<0.001^{*}$ \\
Cefaks & $265.7 \pm 62.8$ & $206 \pm 62.9$ & $229.5 \pm 68.7$ & $0.037^{* \mathrm{~b}}$ \\
Macrol & $313.3 \pm 44.0^{\mathrm{c}}$ & $278.0 \pm 52.0$ & $224.0 \pm 42.0$ & $0.017^{*}$ \\
Ferro Sanol B & $243.3 \pm 50.3^{\mathrm{d}}$ & $207.1 \pm 43.3$ & $190.0 \pm 51.0$ & $0.002^{*}$ \\
Calpol 6 Plus & $335.1 \pm 36.0^{\mathrm{e}}$ & $268.0 \pm 58.0$ & $261.0 \pm 46.2$ & $0.037^{*}$ \\
Atarax & $282.2 \pm 36.0^{\mathrm{f}}$ & $244.0 \pm 55.4^{\mathrm{g}}$ & $167.4 \pm 27.3$ & $<0.001^{*}$ \\
Ventolin & $201.1 \pm 36.0^{\mathrm{h}}$ & $155.0 \pm 46.5^{\mathrm{i}}$ & $101.0 \pm 39.2$ & $<0.001^{*}$ \\
Augmentin & $293.4 \pm 35.5^{\mathrm{j}}$ & $234.0 \pm 53.1$ & $227.1 \pm 83.0$ & $0.017^{*}$ \\
\hline Dolven & $229.1 \pm 38.0^{\mathrm{k}}$ & $146.4 \pm 20.1$ & $139.0 \pm 36.1$ & $<0.001^{*}$ \\
Sudafed & $207.0 \pm 42.0^{\mathrm{l}}$ & $195.0 \pm 25.4^{\mathrm{m}}$ & $130.0 \pm 15.1$ & $<0.001^{*}$ \\
\hline Deltacortril & $312.1 \pm 21.0$ & $285.0 \pm 49.0$ & $268.3 \pm 61.0$ & 0.191 \\
Distilled water & $146.7 \pm 33.6$ & $162.8 \pm 20.6$ & $163.1 \pm 30.3$ & 0.54 \\
\hline
\end{tabular}

Data presented as mean \pm standard deviation (SD): ${ }^{a} p<0.001,0$ vs 7 and 14 ; ${ }^{\mathrm{b}} p=0.037 ;{ }^{\mathrm{c}} p=0.017,0$ vs 7 and $14 ;{ }^{\mathrm{d}} p=0.002,0$ vs 7 and $14 ;{ }^{\mathrm{e}} p=0.037$, 0 vs 7 and $14 ;{ }^{f} p<0.001,0$ vs $7 ;{ }^{9} p<0.001,7$ vs $14 ;{ }^{\text {h }} p<0.001,0$ vs 7 and 14 ; $p<0.001,7$ vs 14; $p=0.017,0$ vs 7 and $14 ;{ }^{k} p<0.001,0$ vs 7 and 14; I $p<0.001,0$ vs $14 ;^{m} p<0.001,7$ vs 14 ; $^{*}$ statistically significant.

\section{Discussion}

In this study, it was observed that all of the drugs used, except for prednisolone $(p=0.191)$, caused a significant decrease in the tooth enamel microhardness in vitro. In the case of prednisolone, a decrease was also observed, but it was not significant $(p>0.05)$. Similarly, researchers have shown that some pediatric drugs that are given to children regularly and for a long time have the erosive potential. ${ }^{23-25}$

The $\mathrm{pH}$ values of the drugs used ranged from 2.76 (pseudoephedrine $\mathrm{HCl}$ ) to 6.62 (paracetamol). The drug whose active substance is pseudoephedrine $\mathrm{HCl}(\mathrm{pH}$ 2.76; TA $3250 \mathrm{mmol}$; BC $3246 \mathrm{mmol}$ ) caused a significant decrease in the microhardness of the samples. This outcome can be attributed to the lower $\mathrm{pH}$ and high TA and $\mathrm{BC}$ levels of the drug and its inactive ingredients. As it is commonly known, a drug with a low $\mathrm{pH}$ value and high TA has the potential to produce abrasive lesions in the teeth if used frequently and/or for a long time. Acidogenicity is defined as the production of oral acid from the sugars found in beverages or drugs, or from refined carbohydrates. Thus, it has been understood that refined carbohydrate concentration and additives modify the properties of the test media used to contribute to $\mathrm{pH}$ and TA. ${ }^{25,26}$

There are 2 ways to measure the acid content of a food or beverage: $\mathrm{pH}$ or total or neutralizable acidity, and $\mathrm{pH}$ or true acidity, which is the negative logarithm of the hydrogen ion concentration. Neutralizable acidity refers to the total number of acid molecules, both protonated and unprotonated, and determines the availability of real hydrogen ions that will interact with the tooth surface. ${ }^{25,27}$

In this study, pseudoephedrine $\mathrm{HCl}$ showed the maximum BC (3246 mmol) and ibuprofen had the greatest TA $(3750 \mathrm{mmol})$. The causes of these differences were thought to be related to the syrup composition, added alcohols as well as the viscosity and surface tension of the syrups and the acids in the formulations. ${ }^{12}$

The liquid pharmaceutical formulations of the drugs that were included in the study are as follows: the antibiotic was clarithromycin (pH 5.15; TA $750 \mathrm{mmol}$ ), the antiepileptic was levetiracetam (pH 5.83; TA $400 \mathrm{mmol}$ ), the bronchodilator was salbutamol (pH 3. 58; TA $3000 \mathrm{mmol}$ ), and the sympathomimetic was pseudoephedrine $\mathrm{HCl}$ (pH 2.76; TA $3250 \mathrm{mmol}$ ), which contains citric acid as an inactive ingredient.

The effect of citric acid was thought to be important in the reduction in microhardness caused by these drugs. Citric acid is the main acid used in medicines and is a powerful erosion agent, as it has the ability to chelate calcium in hydroxyapatite. ${ }^{9}$ Citric acid, ascorbic acid, sugar, diphenhydramine hydrochloride, and ethanol are substances that contribute to acidity, which can be neutralized at low $\mathrm{pH}$.

Drugs in the form of syrups include diphenhydramine hydrochloride, ammonium chloride, sodium citrate, menthol, and ethanol. ${ }^{25}$ In this study, hydroxyzine $\mathrm{HCl}$ 
contained ethanol and the multivitamin ascorbic acid excipients. The microhardness reduction in the samples can be attributed to the low $\mathrm{pH}$ and high TA and $\mathrm{BC}$ values, and the inactive ingredients of the drugs.

Titratable acidity represents the total content of acids and is considered to determine the strength of the erosive potential of the syrup; $\mathrm{BC}$ is the time needed to neutralize the acid in the syrup by the saliva. ${ }^{13}$

Prednisolone (6.36), levetiracetam (5.83), cefuroxime axetil (5.86), paracetamol (6.62), and amoxicillin + clavulanic acid (5.70), which have $\mathrm{pH}$ values above critical $\mathrm{pH}$ (5.5), caused a significant decrease in microhardness, except for prednisolone. This can be attributed to high TA and high $\mathrm{BC}$. A decrease in sample microhardness was observed in the prednisolone drug, but this was not significant. In this case, it is thought that the $\mathrm{pH}$ value of the drug (6.36) is higher than the critical acidity; the $\mathrm{pH}, \mathrm{TA}(40 \mathrm{mmol})$ and $\mathrm{BC}(71 \mathrm{mmol})$ values are low, the sugar contains lactose, and the other excipients also play a role. At the same time, this outcome may be related to the short test duration.

In this study, despite having $\mathrm{pH}$ higher than prednisolone, a significant decrease in microhardness occurred in paracetamol in the applied samples. This effect can be explained by high TA $(200 \mathrm{mmol})$ and BC $(526 \mathrm{mmol})$. Additionally, this decrease can be linked to the inactive ingredients of the drug, such as a sorbitol solution, orange flavor, sucrose, Tween 80, and white sugar. Ibuprofen $(\mathrm{pH} 4.38$; TA $3750 \mathrm{mmol}$; BC $1431 \mathrm{mmol}$ ), amoxicillin + clavulanic acid (pH 5.70; TA $400 \mathrm{mmol}$; BC $308 \mathrm{mmol}$ ), cefuroxime axetil (pH 5.86; TA $800 \mathrm{mmol}$; BC $702 \mathrm{mmol}$ ), and clarithromycin (pH 5.15; TA $750 \mathrm{mmol}$; BC $405 \mathrm{mmol}$ ) caused a significant decrease in microhardness in the samples, which can be attributed to the low $\mathrm{pH}$, high TA and TK values and the inactive ingredients contained.

The samples were exposed to artificial saliva between immersion cycles. The saliva protein-based pellicle emulsifies on the tooth surface and prevents direct contact of the acids and the tooth surface, acting as a diffusion barrier and preventing the demineralization process. Therefore, an artificial saliva substance was used between the immersion cycles to protect the teeth. Care was taken to renew artificial saliva every day to ensure a remineralization effect similar to that of fresh human saliva. ${ }^{13,28}$

Iron(II)-glycine-sulfate complex ( $\mathrm{pH} 2.86)$, which is frequently prescribed from the multivitamin group, was used and caused a significant decrease in microhardness. This drug has high TA $(3500 \mathrm{mmol})$ and BC (845 mmol) values and inactive ingredients, such as ascorbic acid, glucose monohydrate, sorbitol, refined sugar, orange, pear essence, and sulfuric acid, which is an abrasive acid. Similarly, other in vitro studies have observed the erosive effects of certain drugs, such as bronchodilator syrups, iron supplements and antiallergic/expectorant drugs, on the surface roughness and microhardness, and morphological changes have been reported. ${ }^{7-9,11,12,19}$
Salbutamol from the bronchodilator group, used in the present study, has lower $\mathrm{pH}$ (3.58), and higher TA (3000 mmol) and BC (877 mmol) than the critical pH level. Compared to the baseline microhardness values, the decrease in the values for days 7 and 14 was associated with both low $\mathrm{pH}$ and high TA and TK values, and with inactive ingredients, such as salbutamol sulfate and citric acid monohydrate as well as orange flavor.

Contradictory results regarding the relationship between asthma and tooth erosion have been published in the literature. ${ }^{29,30}$ Asthma medications used as inhalers are thought to be more protective against erosion with the help of both higher $\mathrm{pH}$ and the protective effect of the lips. ${ }^{29}$

Drugs that are acidic, however, can directly affect the teeth. When in vivo, it is thought that the long-term use of $\beta 2$-adrenergic stimulants, such as salbutamol, salmeterol or terbutaline, leads to a decrease in the saliva flow and thus reduces the modifying and protective effects of saliva. At the same time, drugs used as bronchodilators are thought to enhance gastroesophageal reflux. Whether or not there is a causal relationship between both conditions is still unknown, but dentists should consider linking the possibility of erosive lesions to possible reflux disease in asthmatic patients. ${ }^{26}$

Sugar or other sweeteners are available in all of the medications used in the study and are thought to increase both the erosive and cariogenic potential of the medicines. Similarly, Xavier et al. found lower values for the antiemetic class drugs without sugar in their composition, and higher erosive and cariogenic potential values for antibiotics and analgesics. ${ }^{31}$ Sugars are multifunctional ingredients added to drug formulations due to the unpleasant taste of many active ingredients. Additionally, sucrose is chemically and physically stable, functions as an oxidant and solvent, is easily processed, is found in different dry particle sizes providing viscosity for the drug, is not hygroscopic, and is less costly, which affects the final product price. Liquid medicines usually have unpleasant taste, so it is necessary to add a variety of sweeteners to the product to overcome this. Commonly used sweeteners are sodium saccharin, sorbitol and sodium cyclamate.

Most of the drugs contain sucrose and citric acid. The replacement of the acidic group, for example using malic acid instead of citric acid, and the use of sweeteners that have been proven to be less cariogenic, such as xylitol or sorbitol, may reduce the erosive and cariogenic effects of drugs. Additionally, drug companies should show the type and amount of sweetener added and label all medicines to indicate the possible adverse effects on teeth. Moreover, medicines with noncariogenic sweeteners may be presented, and 'tooth-friendly' symbols may be placed on the packages. ${ }^{14}$ However, studies have shown that there is a need for further research. ${ }^{2,12,32}$

Finally, this study imitated an in vivo environment, so it may be recommended to evaluate the effects of different active agents on the enamel of primary teeth for a longer time in further studies. 


\section{Conclusions}

Commonly used and prescribed pediatric drugs pose a risk for tooth erosion, and various protective measures should be recommended to parents, dentists and pediatricians. Parents should be informed about the importance of milk and permanent teeth. It may be advisable to rinse the mouth with water or $\mathrm{Ca}, \mathrm{F}$ and $\left(\mathrm{PO}_{4}\right), 3$ added formulations after drug use; to take medications during mealtimes; to pay attention to oral hygiene procedures; not to skip dental appointments in 3-6 months intervals; and to complete fluoride applications. The type and amount of sweeteners added to medications by pharmaceutical companies can be important for creating awareness among pediatricians who prescribe medicines and for parents reading labels that indicate possible adverse effects on teeth. It may also be useful to increase the number of medicines with sweeteners that do not cause erosion and to mark them with 'tooth-friendly' symbols on pharmaceutical markets. Pediatricians should be aware of the effects of prescription drugs on tooth erosion and and emphasize the need for compliancy with oral hygiene procedures. At the same time, we are of the opinion that it would be beneficial to work cooperatively with dentists.

\section{ORCID iDs}

Nagehan Yllmaz (1) https://orcid.org/0000-0001-9523-2899 Ozgul Baygin (10 https://orcid.org/0000-0003-0836-7619

Tugba Nigar Cakıroglu (1) https://orcid.org/0000-0001-9613-6911

Tamer Tüzüner (1) https://orcid.org/0000-0001-5817-5928

Orhan Deger (1) https://orcid.org/0000-0003-3584-6324

\section{References}

1. Cavalcanti AL, De Sousa RI, Clementino MA, Vieira FF, Cavalcanti CL, Xavier AF. In vitro analysis of the cariogenic and erosive potential of paediatric antitussive liquid oral medications. Tanzan J Health Res. 2012;14(2):139-145.

2. Mali GV, Dodamani AS, Karibasappa GN, Kumar PV, Jain VM. Effect of conventional and sugar free pediatric syrup formulations on primary tooth enamel hardness: An in vitro study. J Indian Soc Pedod Prev Dent. 2015;33(4):331-336.

3. Shellis RP, Featherstone JD, Lussi A. Understanding the chemistry of dental erosion. Monogr Oral Sci. 2014;25:163-179.

4. Hicks J, Garcia-Godoy F, Flaitz C. Biological factors in dental caries enamel structure and the caries process in the dynamic process of demineralization and remineralization (part 2). J Clin Pediatr Dent. 2004;28(2):119-124.

5. Zanatta RF, Esper MÂ, Valera MC, Melo RM, Bresciani E. Harmful effect of beer on bovine enamel microhardness - in vitro study. PLoS One. 2016;11(10):e0163440.

6. Mantonanaki M, Koletsi-Kounari H, Mamai-Homata E, Papaioannou W. Dental erosion prevalence and associated risk indicators among preschool children in Athens, Greece. Clin Oral Investig. 2013;17(2):585-593.

7. Zero DT. Etiology of dental erosion - extrinsic factors. Eur J Oral Sci. 1996;104(2 (Pt 2)):162-177.

8. Costa CC, Almeida IC, Costa Filho LC. Erosive effect of an antihistamine-containing syrup on primary enamel and its reduction by fluoride dentifrice. Int J Paediatr Dent. 2006;16(3):174-180.

9. Maguire A, Baqir W, Nunn JH. Are sugars-free medicines more erosive than sugars-containing medicines? An in vitro study of paediatric medicines with prolonged oral clearance used regularly and long-term by children. Int J Paediatr Dent. 2007;17(4):231-238.
10. Nunn JH, Ng SK, Sharkey I, Coulthard M. The dental implications of chronic use of acidic medicines in medically compromised children. Pharm World Sci. 2001;23(3):118-119.

11. Valinoti AC, Neves BG, da Silva EM, Maia LC. Surface degradation of composite resins by acidic medicines and $\mathrm{pH}$-cycling. J Appl Oral Sci. 2008;16(4):257-265.

12. Scatena C, Galafassi D, Gomes-Silva JM, Borsatto MC, Serra MC. In vitro erosive effect of pediatric medicines on deciduous tooth enamel. Braz Dent J. 2014;25(1):22-27.

13. Lussi A, Jaeggi T. Erosion - diagnosis and risk factors. Clin Oral Investig. 2008;12(Suppl 1):S5-S13.

14. Tupalli AR, Satish B, Shetty BR, Battu S, Kumar JP, Nagaraju B. Evaluation of the erosive potential of various pediatric liquid medicaments: An in-vitro study. J Int Oral Health. 2014;6(1):59-65.

15. Lussi A, Carvalho TS. Erosive tooth wear: A multifactorial condition of growing concern and increasing knowledge. Monogr Oral Sci. 2014;25:1-15.

16. Addy $M$, Shellis RP. Interaction between attrition, abrasion and erosion in tooth wear. Monogr Oral Sci. 2006;20:17-31.

17. Nunn JH, Gordon PH, Morris AJ, Pine CM, Walker A. Dental erosion - changing prevalence? A review of British National childrens' surveys. Int J Paediatr Dent. 2003;13(2):98-105.

18. Carvalho TS, Lussi A, Jaeggi T, Gambon DL. Erosive tooth wear in children. Monogr Oral Sci. 2004;25:262-278.

19. Valinoti AC, Pierro VS, Da Silva EM, Maia LC. In vitro alterations in dental enamel exposed to acidic medicines. Int J Paediatr Dent. 2011;21(2):141-150.

20. Yesilyurt C, Sezer U, Ayar MK, Alp CK, Tasdemir T. The effect of a new calcium-based agent, Pro-Argin, on the microhardness of bleached enamel surface. Aust Dent J. 2013;58(2):207-212.

21. McKnight-Hanes $C$, Whitford GM. Fluoride release from three glass ionomer materials and the effects of varnishing with or without finishing. Caries Res. 1992;26(5):345-350.

22. Amaechi BT, Higham SM, Edgar WM. Factors influencing the development of dental erosion in vitro: Enamel type, temperature and exposure time. J Oral Rehabil. 1999;26(8):624-630.

23. Dhawan L, Geetanjali, Narang A, Gill GS, Toor JS, Sandhu SS. In-vitro study for comparative analysis of erosive potential of pediatric liquid medicinal syrups on deciduous teeth. Int J Com Health Med Res. 2017;3(2):92-95.

24. Kulkarni P, Anand A, Bansal A, Jain A, Tiwari U, Agrawal S. Erosive effects of pediatric liquid medicinal syrups on primary enamel: An in vitro comparative study. Indian J Dent. 2016;7(3):131-133.

25. Kaur M, Bhaskar V, Ganesh M, Joshi K, Trivedı K. Comparative evaluation of the erosive potential of commonly used beverages and medicated syrup - an in vitro study. J Ahmedabad Dent Coll Hosp. 2012;3(1):19-25.

26. Hellwig E, Lussi A. Oral hygiene products, medications and drugs - hidden aetiological factors for dental erosion. Monogr Oral Sci. 2014;25:155-162.

27. Tahmassebi JF, Duggal MS, Malik-Kotru G, Curzon ME. Soft drinks and dental health: A review of the current literature. J Dent. 2006;34(1):2-11.

28. Hara AT, Ando M, González-Cabezas C, Cury JA, Serra MC, Zero DT. Protective effect of the dental pellicle against erosive challenges in situ. J Dent Res. 2006;85(7):612-616.

29. Dugmore CR, Rock WP. Asthma and tooth erosion. Is there an association? Int J Paediatr Dent. 2003;13(6):417-424.

30. Al-Dlaigan $\mathrm{YH}$, Shaw $\mathrm{L}$, Smith AJ. Is there a relationship between asthma and dental erosion? A case control study. Int J Paediatr Dent. 2002;12(3):189-200.

31. Xavier AF, Moura EF, Azevedo WF, Vieira FF, Abreu MH, Cavalcanti AL. Erosive and cariogenicity potential of pediatric drugs: Study of physicochemical parameters. BMC Oral Health. 2013;13:71.

32. Pasdar N, Alaghehmand H, Mottaghi F, Tavassoli M. Experimental study of iron and multivitamin drops on enamel microhardness of primary tooth. J Int Soc Prev Community Dent. 2015;5(6):518-524. 